\title{
A Comparative Study of Iron Removal Efficiency by Precipitation Method and Deferrization Unit of DAN DADJI-IIléla Drilling
}

\author{
YAHOUZA ZANEIDOU, MANZOLA ABDOU SALAM* ${ }^{\star}$ AMADOU HAOUA, \\ and LAOUALI MAHAMAN SANI
}

\author{
'Département of Chimie, Faculté de Sciences et Techniques, Université Abdou Moumouni \\ de Niamey BP. 10662 Niamey, Niger. \\ *Corresponding author E-mail: abdoussalam_manzola@yahoo.com
}

http://dx.doi.org/10.13005/ojc/360108

(Received: December 02, 2019; Accepted: January 03, 2020)

\begin{abstract}
The paper is a comparative study on deferrization efficiency of two methods on the waters of rural drilling of Dan Daji (Niger) which have high iron concentration $(1.69 \mathrm{mg} / \mathrm{L})$ : the deferrization by oxidation-precipitation method and the deferrization made by a modern unit of deferrization. Before comparison, a synthetic solution was prepared by adding a certain amount of $\mathrm{FeSO}_{4} \cdot 7 \mathrm{H}_{2} \mathrm{O}$ in bicarbonate aqueous solutions and studied. The natural water was characterized by physicochemical analyzes. The two methods are appropriate for the deferrization of synthetic solutions and Dan Daji Illela iron poisoning field waters. The oxidation-precipitation method can be used as a pretreatment method before the deferrization unit. DRX analyzes of the precipitates obtained showed the coexistence of two (2) solid phases; goethite $(\alpha-\mathrm{FeOOH}) \mathrm{G}$ and lepidocrocite $(\gamma-\mathrm{FeOOH})$ $\mathrm{L}$ for $[\mathrm{HCO}-]=488 \mathrm{mg} / \mathrm{L} ; \mathrm{pHi}=8 ;\left[\mathrm{Fe}^{2+}\right]_{0}=5 \mathrm{mg} / \mathrm{L}$ and $\mathrm{T}=30^{\circ} \mathrm{C}$. For the other iron and bicarbonate concentrations and for the other $\mathrm{pHi}$ studied, the precipitating phase was mainly goethite.
\end{abstract}

Keywords: Precipitation, Deferrization unit, Iron oxyhydroxide, Carbonate medium, Groundwater, initial pH.

\section{INTRODUCTION}

With an ever-increasing population and increasing demographic pressure, Niger faces surface water scarcity as in most arid climate developing countries. To meet the water needs of the population, the Niger Republic government has exploited deepwater aquifers, the only sources of water supply for the population. The increasing demands of water make their exploitation vital for the development of these countries. Since 1996, more than 6207 boreholes and 10005 wells have been drilled. These boreholes play a crucial role in providing water to the population. A study carried out by the Ministry of Hydraulics, Environment and Desertification Control (MHE/LD) in 2005 on the physico-chemical analyzes of water showed that, out of a total of 148 boreholes studied, $28.4 \%$ have

This is an Open Access article licensed under a Creative Commons license: Attribution 4.0 International (CC- BY). Published by Oriental Scientific Publishing Company @ 2018 
an iron concentration well above $0.3 \mathrm{mg} / \mathrm{L}$ (value recommended by WHO). Analyzes by region shows that the percentage of drilling in the regions with iron concentrations above $0.3 \mathrm{mg} / \mathrm{L}$ varies from 16 to 70 \%: $20 \%$ in Diffa region (Bosso 2.34 mg/L), $16 \%$ in Dosso region (Rountoua 2.02 mg/L), $27 \%$ in Maradi region (Halbawa $7.6 \mathrm{mg} / \mathrm{L}$ ) and $70 \%$ in Tahoua region (Kagarki kagarkawa 8.2 mg/L; Edir 5.35 $\mathrm{mg} / \mathrm{L}$; Bagaroua 4.7 mg/L; Hayayé $4.75 \mathrm{mg} / \mathrm{L})$. The highest concentrations were recorded in Tahoua and Maradi regions with 8.2 and $7.6 \mathrm{mg} / \mathrm{L}$ respectively. An overload of iron in the human body can lead to primary hemochromatosis (poor regulation of iron absorption by the intestine) and even liver cancer (risk of liver cancer), these disorders generally occur when the concentration of iron in water is greater than $10 \mathrm{mg} /$ $\mathrm{L}^{1}$. At concentrations above $0.3 \mathrm{mg} / \mathrm{L}$, the presence of iron in water affects the organoleptic qualities of the water (unpleasant taste, smell, and color) and is responsible over time for corrosive deposits in pipes. These formed deposits can be the site of highly toxic bacterial colonies $3,4,5,6,7,8,9,10,11$. In the absence of other resources, groundwater, reserve in Niger, is the only alternative to face this shortage. The exploitation of these groundwater tables is necessary to cover a large part of the enormous water needs of the populations. Unfortunately, most of the groundwater in the Tahoua region has a high content of iron (II) and manganese, leading to insoluble and encrusted deposits of iron oxyhydroxides when these waters are in contact with oxygen in the air. Some of the hydroxides settle as silt and give a rusty color and unpleasant taste to the water ${ }^{12}$. Indeed, once in contact with oxygen in the air, iron (II) oxidizes to iron (III) and precipitates as $\mathrm{Fe}(\mathrm{OH})_{3}$ and probably oxyhydroxides of iron (III). At lower concentrations, the problems associated with the presence of iron in drinking water are aesthetic ${ }^{18,19}$.

The presence of iron in water leads to a certain speciation which corresponds to its distribution between the different physico-chemical species, thus defining the different physico-chemical forms present and their relative evaluation. This speciation is based on the behavior of iron in aqueous solution, it depends on several factors such as $\mathrm{pH}$, initial concentration, temperature and ageing time of the solution, etc. The influence of $\mathrm{pH}$ is directly related to the dissociation equilibria that partly govern the distribution of the different species of iron (II) and iron (III) that can be formed in the solution. These species are generally $\mathrm{Fe}(\mathrm{OH})_{3}$, $\mathrm{Fe}(\mathrm{OH})^{2+}, \mathrm{Fe}(\mathrm{OH})_{4}$ for iron(III) and $\mathrm{Fe}\left(\mathrm{H}_{2} \mathrm{O}\right)_{6}{ }^{+2}, \mathrm{FeCO}_{3}$, $\mathrm{Fe}(\mathrm{OH})_{2}, \mathrm{FeOH}^{+}$for iron(II) ${ }^{20,21}$. The predominance of these species in a solution is related to the stability constants of the iron(II) and Fe(III) complexes, these different constants are recorded in Table $1^{22}$. In view of this worrying situation, it is imperative to take measures to improve the quality of drinking water in rural areas. Currently several methods of iron removal are being developed. These processes include, among others, physico-chemical processes based on the use of stronger or weaker oxidants (chlorine, potassium permanganate, oxygen and ozone), biological processes involving microorganisms, catalytic processes based on adsorption and oxidation on the surface of a specific material and membrane processes $2,7,23,24$. These treatment methods are not without limits in the implementation, both in the use of certain materials and in the control of certain physico-chemical parameters and especially in the accessibility of the necessary materials and chemicals. Among all these methods we have retained the elimination of iron by oxidation precipitation with oxygen from the air in the carbonate medium, in the form of oxyhydroxides (lepidocrocite), which is a method closer to reality and easily accessible ${ }^{4}$.

The objective of the present study was to investigate the performance of the deferrization and precipitation deferrization unit as a feasible and suitable deferrization method. Deferrization studies were carried out under various equilibrating conditions like the effect of initial $\mathrm{pH}$, bicarbonate concentration and iron (II) concentration. Detailed precisions during the deferrization mechanism and the kinetic studies are presented. The precipitated products were characterized by DRX diffraction and FTIR Fourrier Transform Spectroscopy.

\section{MATERIALS AND METHODS}

In our study for precipitation fertilization, we used an assembly consisting of a 1-litre beaker and a mechanical agitator. All manipulations were carried out in the beaker under mechanical agitation at atmospheric pressure and $30^{\circ} \mathrm{C}$ in order to increase the contact between the oxygen in the air and the $\mathrm{Fe}^{2+}$ ions in the solution, which is the driving principle behind the evolution of the system leading to the oxidation of the $\mathrm{Fe}^{2+}$ ions and the precipitation 
of $\mathrm{Fe}(\mathrm{OH})_{3}$. Iron solutions were prepared by introducing variable amounts of $\mathrm{FeSO}_{4} \cdot 7 \mathrm{H}_{2} \mathrm{O}$ iron sulfate heptahydrate into bicarbonated water. The bicarbonated water was prepared by dissolving varying amounts of $\mathrm{NaHCO}_{3}$ in distilled water. The amount of iron was introduced after setting a desired initial $\mathrm{pH}$ value by splashing $\mathrm{CO}_{2}$. The stopwatch and the stirrer are triggered at the same time for a duration of $60 \mathrm{~min}$, which corresponds to the time set for all the experiments. Agitation introduces atmospheric oxygen into the solution. Contact of the solution with atmospheric air causes the release of dissolved $\mathrm{CO}_{2}$, which leads to alkalinization of the medium, resulting in an increase in $\mathrm{pH}$. This increase in $\mathrm{pH}$ favours the oxidation of $\mathrm{Fe}^{2+}$ to $\mathrm{Fe}^{3+}$ and the precipitation of $\mathrm{Fe}(\mathrm{OH})_{3}$. The overall precipitation response is as follows: ${ }^{12}$

$\mathrm{Fe}^{2+}(\mathrm{aq})+2 \mathrm{HCO}_{3}^{-}(\mathrm{aq})+1 / 4 \mathrm{O}_{2}(\mathrm{~g})+1 / 2 \mathrm{H}_{2} \mathrm{O}(\mathrm{l}) \leftrightarrow$ $\mathrm{Fe}(\mathrm{OH})_{3}(\mathrm{~s})+2 \mathrm{CO}_{2} \uparrow$

The iron hydroxide obtained according to the $\mathrm{R} 1$ reaction is very unstable, which explains its evolution towards another iron oxyhydroxide more thermodynamically stable, it is lepidocrocite in its nonhydrated form according to the following reaction:

$\mathrm{Fe}(\mathrm{OH})_{3} \rightarrow \mathrm{FeOOH}+\mathrm{H}_{2} \mathrm{O}$

Several series of tests were performed by varying: the concentration of iron, bicarbonate and pHinitial. Iron solutions were prepared by introducing variable amounts of $\mathrm{FeSO}_{4} .7 \mathrm{H}_{2} \mathrm{O}$ iron sulfate heptahydrate into bicarbonated water. Three (3) iron concentrations were studied in our study: $5 \mathrm{mg} / \mathrm{L}$, $10 \mathrm{mg} / \mathrm{L}$ and $15 \mathrm{mg} / \mathrm{L}$ by dissolving $24.82 \mathrm{mg} ; 49.64$ $\mathrm{mg}$ and $74.46 \mathrm{mg}$ of $\mathrm{FeSO}_{4} \cdot 7 \mathrm{H}_{2} \mathrm{O}$ respectively in a 1-litre vial. The bicarbonated water was prepared by dissolving varying amounts of $\mathrm{NaHCO}_{3}$ in distilled water. Three (3) bicarbonate solutions of different concentrations were prepared: $122 \mathrm{mg} / \mathrm{L}, 244 \mathrm{mg} / \mathrm{L}$ and $488 \mathrm{mg} / \mathrm{L}$. The effect of iron concentration, bicarbonate concentration and initial $\mathrm{pH}$ was studied. The initial $\mathrm{pH}$ values were determined by splashing $\mathrm{CO}_{2}$ into the bicarbonated water. For our experiment, the initial $\mathrm{pH}$ values studied are: $\mathrm{pHi}$, $\mathrm{pHi} 7$ and $\mathrm{pHi} 8$. To determine the concentration of iron in solution during the precipitation experiment, $1 \mathrm{~mL}$ samples were taken using a $5 \mathrm{~mL}$ syringe with a $0.45 \mu \mathrm{m}$ membrane filtration system. Samples of $1 \mathrm{~mL}$ were taken every $2 \mathrm{~min}$ then every $10 \mathrm{~min}$ of precipitation. To the $1 \mathrm{~mL}$ sampled, we successively added $1 \mathrm{~mL}$ hydroxylamine, $2 \mathrm{~mL}$ ammonium acetate and $2 \mathrm{~mL}$ orthophenanthroline. After introducing these reagents, the mixture was completed to $50 \mathrm{~mL}$ with distilled water in a $50 \mathrm{~mL}$ vial. Iron levels were analyzed using a Zuzi Spectrophotometer model 4101 spectrophotometer at a wavelength of $510 \mathrm{~nm}$. The $\mathrm{pH}$ was measured using a $\mathrm{pH}$ meter marked VWR pHenomenal $\mathrm{pH} 1100 \mathrm{H}$. The obtained solids were filtered through a $0.45 \mu \mathrm{m}$ filter, then characterized by X-ray diffraction (XRD). XRD was carried out at room temperature with a Philips X' PERT PRO diffractometer in step scanning mode using CuK $\alpha$ radiation. The XRD patterns were recorded in the scanning range $2 \theta=15$ - $60^{\circ}$. A small angular step of $2 \theta=0.017^{\circ}$ and a fixed counting time of $4 \mathrm{~s}$ were used.

\section{RESULTS AND DISCUSSION}

\section{Precipitation in aqueous solutions with $\left[\mathrm{HCO}_{3}^{-}\right]=0 \mathrm{mg} / \mathrm{L}$}

The $1.0 \mathrm{~L}$ of free bicarbonate aqueous solution consisting of deionized water, with an initial $\mathrm{pH}$ of 5.87 was introduced into the cell. An amount of $\mathrm{FeSO}_{4} .7 \mathrm{H}_{2} \mathrm{O}$ is added to the solution and the experiment is started. Iron (II) concentration and $\mathrm{pH}$ are recorded. Fig. $1 \mathrm{a}$ and $1 \mathrm{~b}$ show iron (II) concentration and $\mathrm{pH}$ evolution versus time.

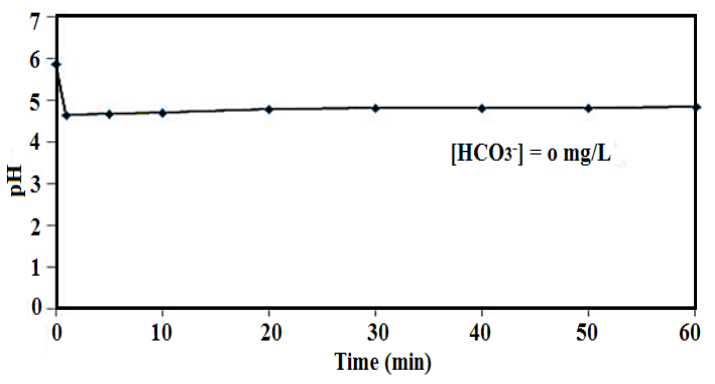

Fig. 1a. $\mathrm{pH}$ evolution during iron precipitation for $\left[\mathrm{HCO}_{3}{ }^{-}\right]=$ $0 \mathrm{mg} / \mathrm{L} ; \mathrm{pHi}=5.87 ;\left[\mathrm{Fe}^{2+}\right]_{0} \mathrm{mg} / \mathrm{L}$ at $30^{\circ} \mathrm{C}$



Fig. 1b. Evolution of the dissolved iron content during iron precipitation for $\left[\mathrm{HCO}_{3}{ }^{-}\right]=0 \mathrm{mg} / \mathrm{L} ; \mathrm{pHi}=5.87 ;\left[\mathrm{Fe}^{2+}\right]_{0}=5 \mathrm{mg}$ at $30^{\circ} \mathrm{C}$ 
Figure 1a shows an abrupt drop of $\mathrm{pH}$ immediately when Iron (II) is added but the iron (II) concentration remains constant at $5 \mathrm{mg} / \mathrm{L}$ (Fig.1b). The reached $\mathrm{pH}$ is 4.66 within a minute. The drop of $\mathrm{pH}$ is accompanying by $\mathrm{H}^{+}$liberation according to the reaction:

$\mathrm{Fe}^{2+}+2 \mathrm{H}_{2} \mathrm{O} \quad \mathrm{Fe}(\mathrm{OH})^{2+} 2 \mathrm{H}^{+}$

Consequently there is not precipitation with deionized water when bicarbonate concentration $\left[\mathrm{HCO}_{3}^{-}\right]=0 \mathrm{mg} / \mathrm{L}$. In the aim of massive and fast precipitation, bicarbonate solutions were used.

\section{Precipitation experiments-synthetic solutions} Synthetic solutions-Influence of $\mathrm{HCO}_{3}^{-}$concentration

To study the influence of the presence of bicarbonate in the precipitation medium and the effect of its concentration, we conducted 4 tests at different concentrations : $\left[\mathrm{HCO}_{3}^{-}\right]=122 \mathrm{mg} / \mathrm{L} ; 244$ $\mathrm{mg} / \mathrm{L}$ and $488 \mathrm{mg} / \mathrm{L}$ for $\mathrm{pHi}=8 ;\left[\mathrm{Fe}^{2+}\right]_{0}=5 \mathrm{mg} / \mathrm{L}$ and at $30^{\circ} \mathrm{C}$. The results are shown in Fig. $2 \mathrm{a}$ and $2 \mathrm{~b}$.

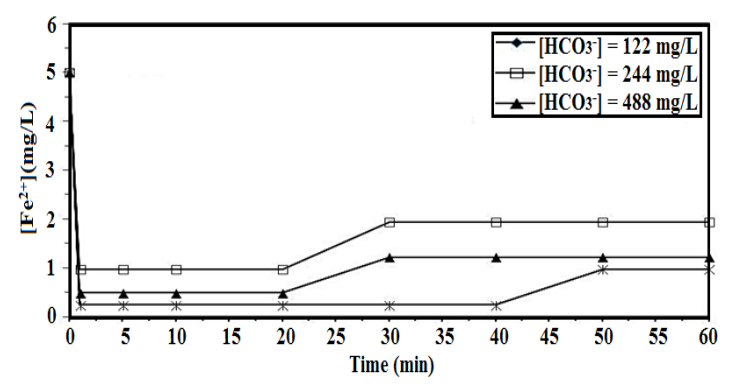

Fig. 2a. Evolution of the dissolved iron content during iron precipitation at different concentrations $\left[\mathrm{HCO}_{3}{ }_{3}^{-}\right] ; \mathrm{pHi}=8$; $\left[\mathrm{Fe}^{2+}\right]_{0}=5 \mathrm{mg}$ at $30^{\circ} \mathrm{C}$

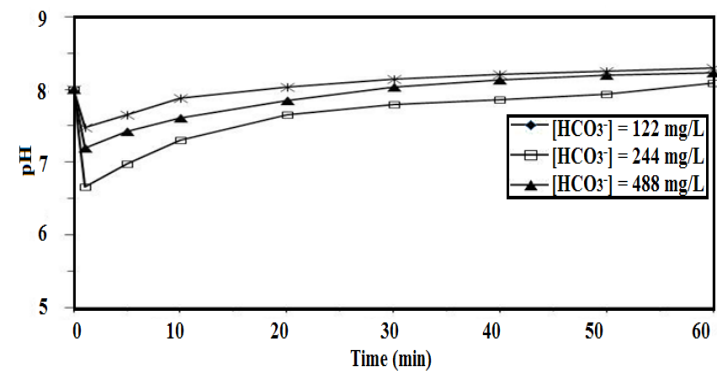

Fig. 2b. pH evolution during iron precipitation at different concentrations $\left[\mathrm{HCO}_{3}^{-}\right] ; \mathrm{pHi}=8 ;\left[\mathrm{Fe}^{2+}\right]_{0} 5 \mathrm{mg} / \mathrm{L}$ at $30^{\circ} \mathrm{C}$

The results presented in Fig. 2a shows the influence of the presence of bicarbonate and the effect of its concentration. This presence causes a sudden drop in iron concentration, and the higher the bicarbonate concentration, the higher the drop.
Thus in less than $2 \mathrm{~min}$ for a concentration of $\left[\mathrm{HCO}_{3}^{-}\right]$ $=122 \mathrm{mg} / \mathrm{L}$ the iron content drops to $\left[\mathrm{Fe}^{2+}\right]=0.97$ $\mathrm{mg} / \mathrm{L}$ or an $80 \%$ elimination, for $\left[\mathrm{HCO}_{3}^{-}\right]=244 \mathrm{mg} / \mathrm{L}$ it drops to $\left[\mathrm{Fe}^{2+}\right]=0.485 \mathrm{mg} / \mathrm{L}$ or an elimination of $90 \%$, and finally for $\left[\mathrm{HCO}_{3}^{-}\right]=488 \mathrm{mg} / \mathrm{L}$ the iron content drops to $\left[\mathrm{Fe}^{2+}\right]=0.242 \mathrm{mg} / \mathrm{L}$ or an elimination of $97 \%$. The $\mathrm{HCO}_{3}$ concentration $488 \mathrm{mg} / \mathrm{L}$ and initial $\mathrm{pH} 8$ could bring down the level of $\mathrm{Fe}^{2+}$ within the tolerance limit, $\left[\mathrm{Fe}^{2+}\right]=0.242 \mathrm{mg} / \mathrm{L}(\mathrm{WHO}$ guideline value $=0.3$ $\mathrm{mg} / \mathrm{L}$ ). Iron precipitation is immediately followed by a drop in $\mathrm{pH}$ (Fig. 2b). The higher the concentration of bicarbonate increases, the poorer the drop. The largest drop is observed for $\left[\mathrm{HCO}_{3}^{-}\right]=122 \mathrm{mg} / \mathrm{L}$, where the $\mathrm{pH}$ has reached 6.656 for an initial $\mathrm{pH}$ of 8 . bicarbonate ions make the medium slightly alkaline, favorable not only to the oxidation of $\mathrm{Fe}^{2+}$ but also to the precipitation of certain iron oxyhydroxides such as lepidocrocite ${ }^{12,13,14,15,16,17}$. The oxidation reaction of $\mathrm{Fe}^{2+}$ iron in the presence of oxygen without bicarbonate leads to the formation of $\mathrm{Fe}^{3+}$ ferric ions, as indicated in the equation of the following reaction:

$4 \mathrm{Fe}^{2+}+\mathrm{O}_{2}+2 \mathrm{H}_{2} \mathrm{O} \rightarrow 4 \mathrm{Fe}^{3+}+4 \mathrm{OH}^{-}$

The ferric iron thus formed, after undergoing hydrolysis mechanisms, precipitates as ferric hydroxide $\mathrm{Fe}(\mathrm{OH})_{3}$ according to the following precipitation reaction:

$4 \mathrm{Fe}^{3+}+4 \mathrm{OH}^{-}+8 \mathrm{H}_{2} \mathrm{O} \rightarrow 4 \mathrm{Fe}(\mathrm{OH})_{3}+8 \mathrm{H}^{+}$

The combination of R3 and R4 gives the overall reaction of the precipitation:

$4 \mathrm{Fe}^{2+}+\mathrm{O}_{2}+10 \mathrm{H}_{2} \mathrm{O} \rightarrow 4 \mathrm{Fe}(\mathrm{OH})_{3}+8 \mathrm{H}^{+}$

The $\mathrm{H}^{+}$protons released during the R5 reaction acidify the medium, preventing iron precipitation. On the other hand, in the bicarbonate medium, these protons will react with the bicarbonate ions $\mathrm{HCO}_{3}^{-}(\mathrm{R} 1)$ and maintain the basic medium causing a rapid and massive precipitation of iron oxyhydroxides, confirming the results obtained by Wided et al., ${ }^{12}$. From the 25 th min onwards, iron oxide was redissolved according to the $\mathrm{R} 6$ reaction, leading to an increase in $\mathrm{Fe}^{2+}$ concentration and an increase in $\mathrm{pH}$ (Fig. 2b). The highest redissolution was observed for $\left[\mathrm{HCO}_{3}^{-}\right]=122 \mathrm{mg} / \mathrm{L}$ where the iron content has increased to $\left[\mathrm{Fe}^{2+}\right]=1.941 \mathrm{mg} / \mathrm{L}$, probably due to a high production of $\mathrm{H}^{+}$protons on the one hand, and a low consumption of $\mathrm{H}^{+}$ions by the bicarbonate ion on the other hand. 


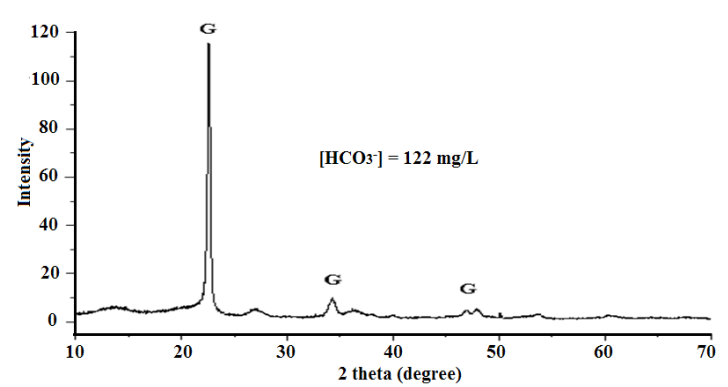

a.) $\left[\mathrm{HCO}_{3}\right]=122 \mathrm{mg} / \mathrm{L},\left[\mathrm{Fe}^{2+}\right]_{0}=5 \mathrm{mg} / \mathrm{L} \mathrm{pHi}=8$ and $\mathrm{T}=30^{\circ} \mathrm{C}$



b.) $\left[\mathrm{HCO}_{3}\right]=244 \mathrm{mg} / \mathrm{L},\left[\mathrm{Fe}^{2+}\right]_{0}=5 \mathrm{mg} / \mathrm{L} \mathrm{pHi}=8$ and $\mathrm{T}=30^{\circ} \mathrm{C}$

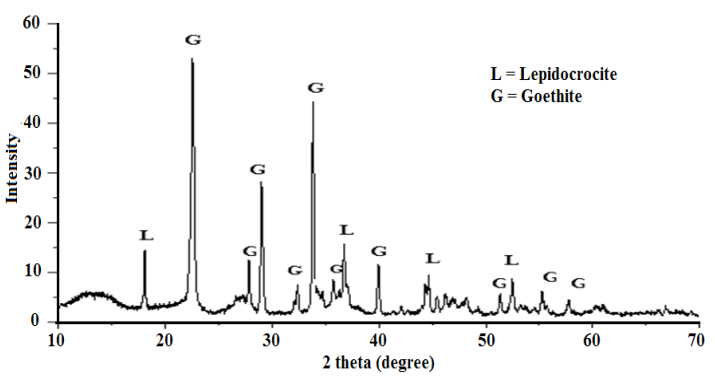

c.) $\left[\mathrm{HCO}_{3}\right]=488 \mathrm{mg} / \mathrm{L},\left[\mathrm{Fe}^{2+}\right]_{0}=5 \mathrm{mg} / \mathrm{L} \mathrm{pHi}=8$ and $\mathrm{T}=30^{\circ} \mathrm{C}$

Fig. 2c. a, b and c. X-ray diffractograms of precipitate obtained at the different $\left[\mathrm{HCO}_{3}^{-}\right]$

The solids formed during these experiments were filtered through a $0.45 \mu \mathrm{m}$ membrane, dried at room temperature and then analyzed by X-ray diffraction (XRD). The diffractograms obtained for different bicarbonate concentrations, at $\left[\mathrm{Fe}^{2+}\right]_{0}=$ $5 \mathrm{mg} / \mathrm{L} ; \mathrm{pHi}=8$ and $\mathrm{T}=30^{\circ} \mathrm{C}$ are shown in Fig. 2c. The analyzes of these diffractograms shows the coexistence of two (2) varieties of crystallized iron oxyhydroxides for $\left[\mathrm{HCO}_{3}^{-}\right]=488 \mathrm{mg} / \mathrm{L}$ : goethite $(\alpha-\mathrm{FeOOH})$ noted $\mathrm{G}$ and lepidocrocite $(\gamma-\mathrm{FeOOH})$ noted $\mathrm{L}^{25,26,27}$. For other lower concentrations, lepidocrocite disappears (Fig. 2c). Conflicting results have been observed by other authors. Music et al., ${ }^{11}$ and Legrand et al., ${ }^{12,18}$ discovered on their part that the presence of bicarbonate in solution prevents the formation of lepidocrocite. These authors explained that bicarbonate ions can incorporate into the precipitation structure and inhibit their crystallization, resulting in an amorphous end product.
Synthetic solutions - Influence of initial pH

To study the effect of $\mathrm{pHi}$ we performed 4 tests at different pHi: $6 ; 7$ and 8 for $\left[\mathrm{HCO}_{3}^{-}\right]=488$ $\mathrm{mg} / \mathrm{L},\left[\mathrm{Fe}^{2+}\right]_{0}=5 \mathrm{mg} / \mathrm{L}$ at $\mathrm{T}=30^{\circ} \mathrm{C}$. The results are shown in Figures $3 a$ and $3 b$.

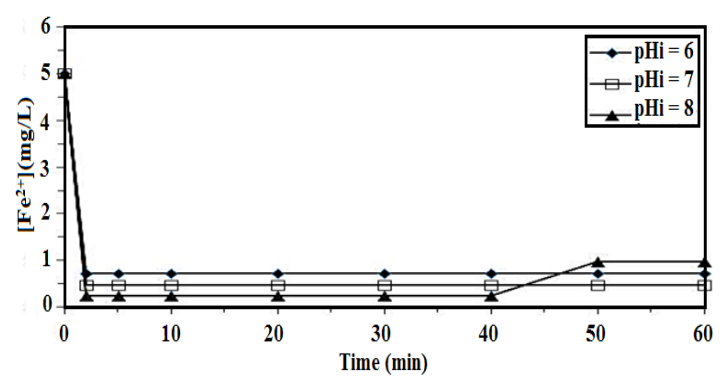

Fig. 3a. Evolution of the dissolved iron content during iron precipitation at different $\mathrm{pHi}$ values for $\left[\mathrm{Fe}^{2+}\right]_{0}=5 \mathrm{mg} / \mathrm{L}$; $\left[\mathrm{HCO}_{3}^{-}\right]=488 \mathrm{mg} / \mathrm{L}$ and at $30^{\circ} \mathrm{C}$

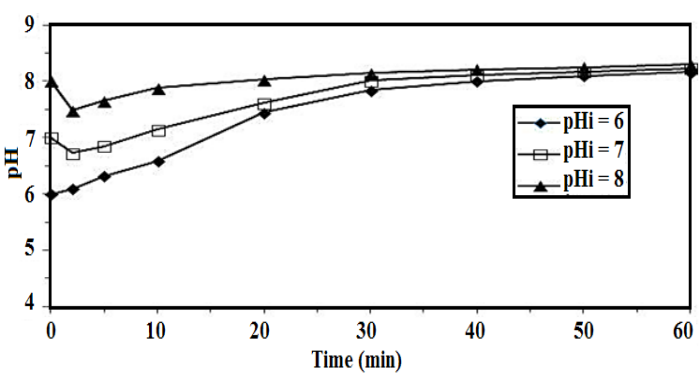

Fig. 3b. Evolution of the $\mathrm{pH}$ during iron precipitation at the different $\mathrm{pHi}$ values for $\left[\mathrm{Fe}^{2+}\right]_{0}=5 \mathrm{mg} / \mathrm{L} ;\left[\mathrm{HCO}_{3}^{-}\right]=488 \mathrm{mg} / \mathrm{L}$ and at $30^{\circ} \mathrm{C}$

Figure 3a shows the evolution curves of the iron(II) concentration as a function of time for different $\mathrm{pHi}$. Examination of these curves shows that the higher the $\mathrm{pHi}$ increases, the more massive the precipitation of iron. Indeed, at $\mathrm{pHi}=8$, more than $95.16 \%$ of the ferrous iron was removed for a precipitation time of less than $2 \mathrm{~min}$, the iron content drops to $\left[\mathrm{Fe}^{2+}\right]_{0}=$ $0.242 \mathrm{mg} / \mathrm{L}$, confirming Catherine Lessard's work in $1999^{23}$, which showed that iron oxidation by oxygen is much more important and instantaneous when the $\mathrm{pH}$ is around 8. This precipitation leads to the instant formation of $\mathrm{Fe}(\mathrm{OH})_{3}$ at around $\mathrm{pH} 8^{12,23}$. For $\mathrm{pHi}=$ 7 the iron content drops to $\left[\mathrm{Fe}^{2+}\right]_{0}=0.485 \mathrm{mg} / \mathrm{L}$ or $90.40 \%$ elimination and for $\mathrm{pHi}=6$ the iron content drops to $\left[\mathrm{Fe}^{2+}\right]_{0}=0.73 \mathrm{mg} / \mathrm{L}$ or $85 \%$ elimination.

These results clearly show that the oxidation-precipitation process of ferrous iron by oxygen from the air is also important even in bicarbonate media with a pHi of 6 or less. From the results presented in Fig. $3 a$ we also note that the oxidation-precipitation phenomenon is instantaneous at all the $\mathrm{pHi}$ studied, unlike the results obtained by ${ }^{12}$ 
which shows that the oxidation-precipitation process is instantaneous only at $\mathrm{pHi}$ 8. This can be explained from the $\mathrm{Fe}^{2+}$ concentration used in our tests, which is in the order of $5 \mathrm{mg} / \mathrm{L}$ instead of $25 \mathrm{mg} / \mathrm{L}$ used by ${ }^{12}$. From the $40^{\text {th }}$ min onwards, iron oxide is redissolved according to the $\mathrm{R} 6$ reaction, resulting in an increase in $\mathrm{Fe}^{2+}$ concentration and an increase in $\mathrm{pH}$ (Fig. 3b) only for $\mathrm{pHi}=8$. This redissolution resulted in an increase in iron content to $\left[\mathrm{Fe}^{2+}\right]_{0}=0.97 \mathrm{mg} / \mathrm{L}$, less significant than that obtained for $\left[\mathrm{HCO}_{3}^{-}\right]=122 \mathrm{mg} / \mathrm{L}\left(\left[\mathrm{Fe}^{2+}\right]_{0}=\right.$ $1.941 \mathrm{mg} / \mathrm{L}$ ) at the same $\mathrm{pHi}=810$. The solids formed during these experiments were filtered through a 0.45 $\mu \mathrm{m}$ membrane, dried at room temperature and then analyzed by $\mathrm{X}$-ray diffraction (XRD). The diffractograms obtained for the different $\mathrm{pHi}$ at $\left[\mathrm{Fe}^{2+}\right]_{0}=5 \mathrm{mg} / \mathrm{L}$; $\left[\mathrm{HCO}_{3}^{-}\right]$ $=488 \mathrm{mg} / \mathrm{L}$ and $\mathrm{T}=30^{\circ} \mathrm{C}$ are shown in Figure $3 \mathrm{c}$.

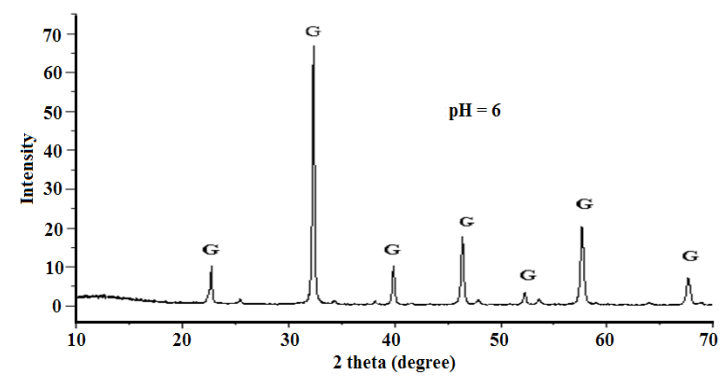

a.) $\left[\mathrm{HCO}_{3}{ }^{-}\right]=488 \mathrm{mg} / \mathrm{L},\left[\mathrm{Fe}^{2+}\right]_{0}=5 \mathrm{mg} / \mathrm{L} \mathrm{pHi}=6$ and $\mathrm{T}=30^{\circ} \mathrm{C}$

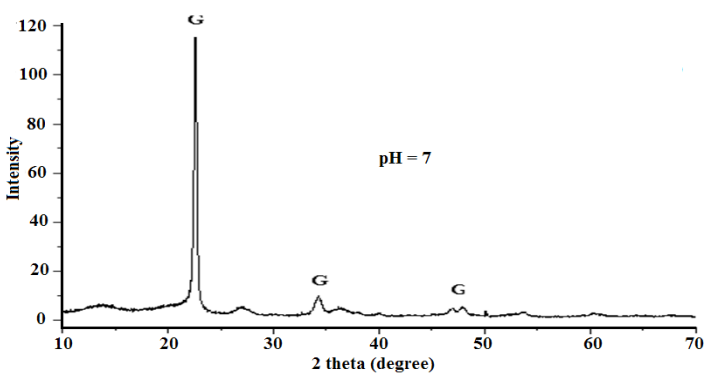

b.) $\left[\mathrm{HCO}_{3}^{-}\right]=488 \mathrm{mg} / \mathrm{L},\left[\mathrm{Fe}^{2+}\right]_{0}=5 \mathrm{mg} / \mathrm{L} \mathrm{pHi}=7$ and $\mathrm{T}=30^{\circ} \mathrm{C}$

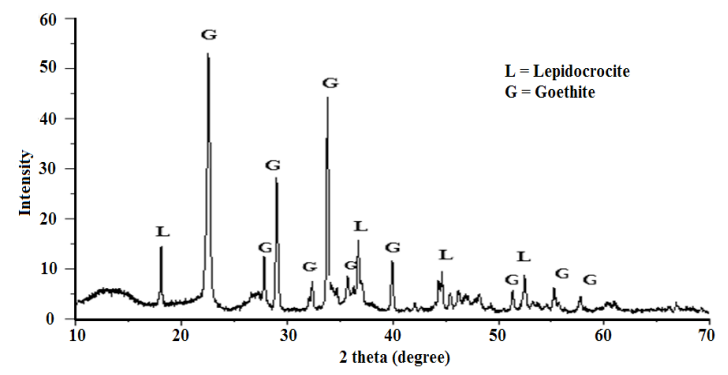

c.) $\left[\mathrm{HCO}_{3}^{-}\right]=488 \mathrm{mg} / \mathrm{L},\left[\mathrm{Fe}^{2+}\right]_{0}=5 \mathrm{mg} / \mathrm{L} \mathrm{pHi}=8$ and $\mathrm{T}=30^{\circ} \mathrm{C}$

Fig. 3c. a, b and c. X-ray diffractograms of the precipitates obtained at the different $\mathrm{pHi}$
The analysis of these diffractograms shows the coexistence of two (2) varieties of crystallized iron oxyhydroxides for $\mathrm{pHi}=8$ : goethite $(\alpha-\mathrm{FeOOH})$ noted $\mathrm{G}$ and lepidocrocite $(\gamma-\mathrm{FeOOH})$ noted $\mathrm{L}^{26}$. For the other lower $\mathrm{pHi}$, lepidocrocite disappears (Fig. 2c). As pHi decreases, goethite crystallizes more and more. Conflicting results have been observed by other authors. Indeed, Wided, $2017^{12}$ found that precipitation of iron in a bicarbonate medium of high concentration and $\mathrm{pH}=8$ only promotes the formation of an amorphous iron oxyhydroxide (ferrihydrite). So the precipitation of iron in the neutral bicarbonate medium promotes the production of goethite. Fig. $3 \mathrm{c}$ also shows that the diffractogram obtained at $\mathrm{pHi}=6$ is almost identical to that of pure goethite, as reported in the literature $\mathrm{e}^{21,25}$. These results are contradictory to those obtained by ${ }^{12}$ or at $\mathrm{pHi}=6$ and 7 , lepidocrocite is formed.

\section{Synthetic solutions-Influence of the initial $\mathrm{Fe}^{2+}$ concentration}

To study the effect of iron content we conducted 4 tests at different concentrations: $5 \mathrm{mg} / \mathrm{L}$; $10 \mathrm{mg} / \mathrm{L}$ and $15 \mathrm{mg} / \mathrm{L}$ for $\left[\mathrm{HCO}_{3}^{-}\right]=488 \mathrm{mg} / \mathrm{L}, \mathrm{pHi}$ $=8$ and at a temperature of $30^{\circ} \mathrm{C}$. The results are shown in Figures $4 \mathrm{a}$ and $4 \mathrm{~b}$.

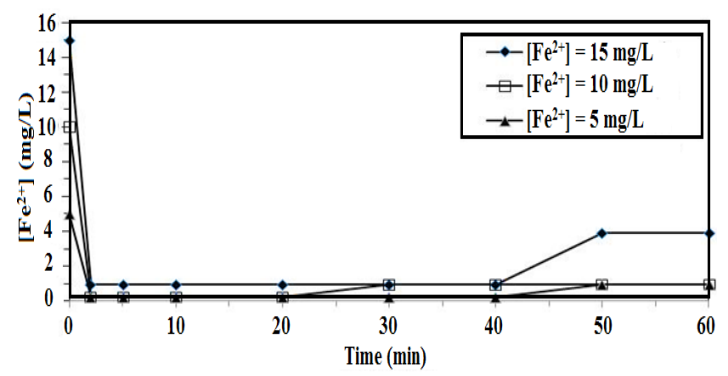

Fig. 4a. Evolution of the dissolved iron content during iron precipitation at different concentrations $\left[\mathrm{Fe}^{2+}\right]_{0} ; \mathrm{pHi}=8$; $\left[\mathrm{HCO}_{3}{ }^{-}\right]=488 \mathrm{mg} / \mathrm{L}$ at $30^{\circ} \mathrm{C}$

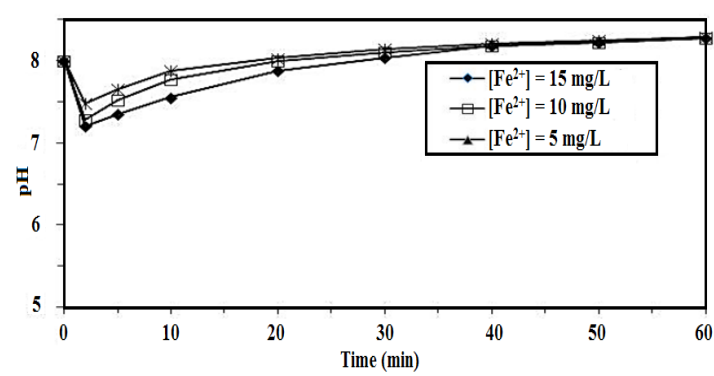

Fig. 4b. Evolution of $\mathrm{pH}$ during iron precipitation at different concentrations $\left[\mathrm{Fe}^{2+}\right]_{0} ; \mathrm{pHi}=8 ;\left[\mathrm{HCO}_{3}^{-}\right]=488 \mathrm{mg} / \mathrm{L}$ at $30^{\circ} \mathrm{C}$ 
The results presented in Fig. 4a show instantaneous precipitation at $\mathrm{pHi}=8$, for all the different initial iron concentrations studied. After about 2 min of precipitation, the iron content drops to $0.2 \mathrm{mg} / \mathrm{L}$ and stabilizes until the $25^{\text {th }}$ min for $\left[\mathrm{Fe}^{2+}\right]_{0}=$ $10 \mathrm{mg} / \mathrm{L}$, after which time there is an increase in the iron content probably due to a redissolution of the precipitated product. This stabilization continues until the $40^{\text {th }}$ min for $\left[\mathrm{Fe}^{2+}\right]_{0}=5 \mathrm{mg} / \mathrm{L}$, after which time there is an increase in iron content as before, resulting in an iron removal rate of $96 \%$ for each situation. For the initial iron concentration $\left[\mathrm{Fe}^{2+}\right]_{0}=15 \mathrm{mg} / \mathrm{L}$, the iron content drops to $0.98 \mathrm{mg} / \mathrm{L}$ (elimination rate $80.40 \%$ ), stabilizes until the $40^{\text {th }}$ minute, at which time there is an increase in iron content to $\left[\mathrm{Fe}^{2+}\right]=3.88$ $\mathrm{mg} / \mathrm{L}$. These results indicate that iron removal is more important when the iron concentration is low. This can be explained from the oxidation-precipitation mechanism, during which protons are released according to the amount of $\mathrm{Fe}(\mathrm{II})$ initially introduced into the solution. We find that the higher the initial $\mathrm{Fe}(\mathrm{II})$ content, the higher the production of $\mathrm{H}^{+}$ions (Fig. 4b), leading to a redissolution of precipitates in the immediate vicinity of these protons according to equation (R6). These results allow us to affirm that, the higher the iron content, the greater the redissolution of $\mathrm{Fe}(\mathrm{OH})_{3}$ is according to the reaction equation R6.

$\mathrm{Fe}(\mathrm{OH})_{3}(\mathrm{~s})+3 \mathrm{H}^{+}(\mathrm{aq}) \rightarrow \mathrm{Fe}^{2+}+3 \mathrm{H}_{2} \mathrm{O}$

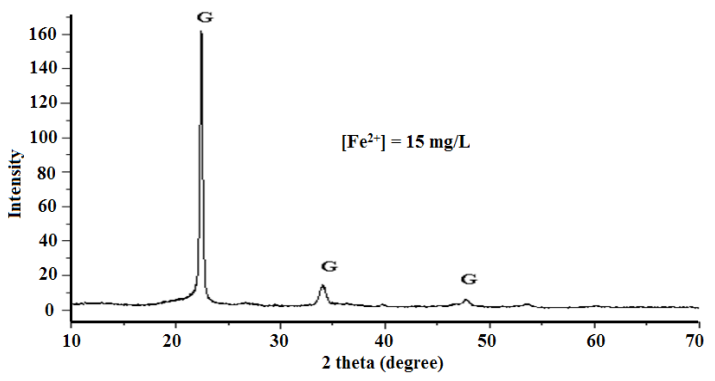

a). $\left[\mathrm{HCO}_{3}^{-}\right]=488 \mathrm{mg} / \mathrm{L},\left[\mathrm{Fe}^{2+}\right]_{0}=15 \mathrm{mg} / \mathrm{L}, \mathrm{pHi}=8$ and $\mathrm{T}=30^{\circ} \mathrm{C}$

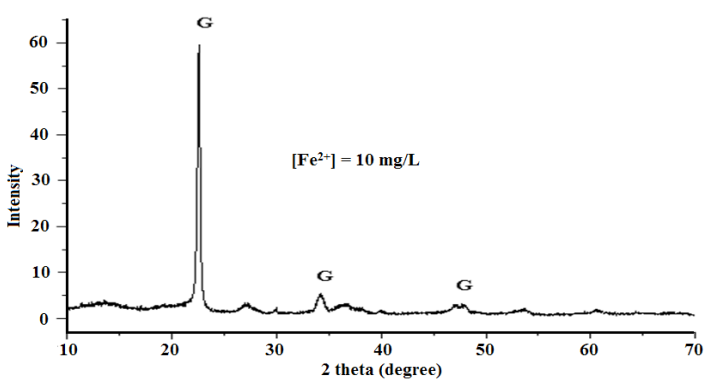

b). $\left[\mathrm{HCO}_{3}{ }^{-}\right]=488 \mathrm{mg} / \mathrm{L},\left[\mathrm{Fe}^{2+}\right]_{0}=10 \mathrm{mg} / \mathrm{L}, \mathrm{pHi}=8$ and $\mathrm{T}=30^{\circ} \mathrm{C}$

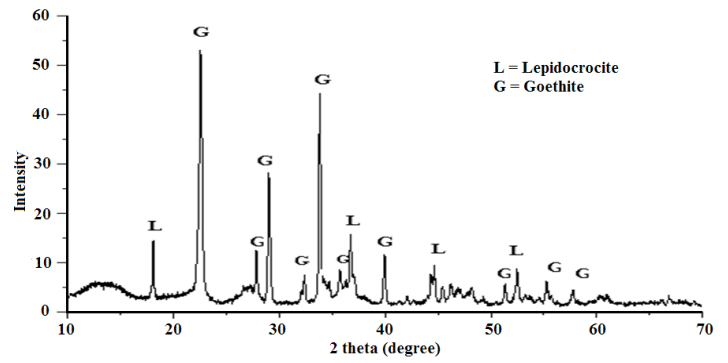

c.) $\left[\mathrm{HCO}_{3}^{-}\right]=488 \mathrm{mg} / \mathrm{L},\left[\mathrm{Fe}^{2+}\right]_{0}=5 \mathrm{mg} / \mathrm{L}, \mathrm{pHi}=8$ and $\mathrm{T}=30^{\circ} \mathrm{C}$

Fig. 4c. a, b and c. X-ray diffractograms of the precipitates obtained at the different $\left[\mathrm{Fe}^{2+}\right]_{0}$

The solids formed during these experiments were filtered through a $0.45 \mu \mathrm{m}$ membrane, dried at room temperature and then analyzed by $\mathrm{X}$-ray diffraction (XRD). The diffractograms obtained for the different initial concentrations of iron $\mathrm{pHi}=8$; $\left[\mathrm{HCO}_{3}{ }^{-}\right]=488 \mathrm{mg} / \mathrm{L}$ and $\mathrm{T}=30^{\circ} \mathrm{C}$ are shown in Fig. 4c. The analysis of these diffractograms shows the coexistence of two (2) varieties of crystallized iron oxyhydroxides for $\left[\mathrm{Fe}^{2+}\right]_{0}=5 \mathrm{mg} / \mathrm{L}$ : goethite $(\alpha-\mathrm{FeOOH})$ noted $\mathrm{G}$ and lepidocrocite $(\gamma-\mathrm{FeOOH})$ noted $L^{27}$. For the other initial iron concentrations of $10 \mathrm{mg} / \mathrm{L}$ and $15 \mathrm{mg} / \mathrm{L}$ the diffractograms are identical. These diffractograms are also identical to the diffractogram obtained for $\left[\mathrm{HCO}_{3}^{-}\right]=488 \mathrm{mg} / \mathrm{L}$; $\left[\mathrm{Fe}^{2+}\right]_{0}=5 \mathrm{mg} / \mathrm{L} ; \mathrm{pHi}=7$ and $\mathrm{T}=30^{\circ} \mathrm{C}$ which states that the precipitation of iron in the neutral bicarbonate medium promotes the production of goethite.

\section{Precipitation experiments-Raw water of the DAN DAJI-ILLELA drilling-effect of $\mathrm{HCO}_{3}{ }^{-}$concentration}

In the second series of experiments the efficiency of oxidation deferrization and deferrization by the DAN DADJI deferrization unit - Illéla was tested with natural water from the DAN DADJI drilling - Illéla under the same conditions as those of synthetic solutions. The physico-chemical characteristics of the drilling water before and after the DAN DADJI Illéla deferrization unit are shown in Table 1

Table 1: The results of the analysis of the physicochemical parameters before and after the deferrizer

\begin{tabular}{ccc}
\hline $\begin{array}{l}\text { Physico-chemical } \\
\text { parameters }(\mathrm{mg} / \mathrm{L})\end{array}$ & Before deferrizer & After deferrizer \\
\hline $\mathrm{pH}$ & & \\
$\mathrm{CE}(\mu \mathrm{S} / \mathrm{cm})$ & 7.35 & 7.25 \\
$\mathrm{~T}\left({ }^{\circ} \mathrm{C}\right)$ & 212 & 209 \\
$\mathrm{SO}^{2-}$ & 26.5 & 26.1 \\
$\mathrm{~F}^{4}$ & 36 & 37 \\
$\mathrm{HCO}^{-3}$ & 0.03 & 0.33 \\
$\mathrm{NO}^{-}$ & 37.5 & 37.5 \\
$\mathrm{NO}^{3}$ & 1.32 & 1.76 \\
$\mathrm{Cl}^{2}$ & 0.0099 & 0.0099 \\
$\mathrm{Fe}^{2+}$ & 1 & 1 \\
$\mathrm{Na}^{+2}$ & 1.69 & 0.136 \\
$\mathrm{Ca}^{2+}$ & 7049 & 7.43 \\
$\mathrm{Mg}^{2+}$ & 12 & 12 \\
$\mathrm{~K}^{+}$ & 4.35 & 4.35 \\
$\mathrm{Mn}^{2+}$ & 15.93 & 15 \\
& 1.2 & 1.2 \\
\hline
\end{tabular}


The results in Table I show that the physical parameters $(\mathrm{pH}$, electrical conductivity and temperature) and most chemical parameters $\left(\mathrm{SO}_{4}^{2-}, \mathrm{F}^{-}, \mathrm{HCO}_{3}{ }_{3}, \mathrm{NO}_{3}{ }^{-}, \mathrm{NO}_{2}^{-}, \mathrm{Cl}^{-}, \mathrm{Mg}^{2+}, \mathrm{K}^{+}, \mathrm{Na}^{+}, \mathrm{Ca}^{2+}\right.$ and $\mathrm{Mn}^{2+}$ ) are practically unchanged, before and after the deferrizer, only the $\mathrm{Fe}^{2+}$ content evolved from $\left[\mathrm{Fe}^{2+}\right]=1.69 \mathrm{mg} / \mathrm{L}$ to $0.136 \mathrm{mg} / \mathrm{L}$, i.e. an iron removal rate of $91.95 \%$, confirming the efficiency of the deferrization unit. Consequently, the deferrization unit of DAN DAJI - ILLELA could bring down the level of $\mathrm{Fe}^{2+}$ within the tolerance limit, $\left[\mathrm{Fe}^{2+}\right]=0.136$ $\mathrm{mg} / \mathrm{L}(\mathrm{WHO}$ guideline value $=0.3 \mathrm{mg} / \mathrm{L})$. Indeed, currently the water from the DAN DAJI - ILLELA borehole is treated using a deferrization unit installed in ILLELA. The deferrizer constantly breaks down, causing recurrent shortages of drinking water. For alternative solutions a series of deferrization tests by the precipitation method was carried out on these waters by varying the quantity of bicarbonate under the same conditions as the synthetic solutions. The different concentrations studied are: $\left.\mathrm{HCO}_{3}^{-}\right]=37.5$ $\mathrm{mg} / \mathrm{L} ; 122 \mathrm{mg} / \mathrm{L} ; 244 \mathrm{mg} / \mathrm{L}$ and $488 \mathrm{mg} / \mathrm{L}$ for $\mathrm{pHi}=$ $7.35,\left[\mathrm{Fe}^{2+}\right]_{0}=1.69 \mathrm{mg} / \mathrm{L}$ and at $30^{\circ} \mathrm{C}$. The results are shown in Figures $5 \mathrm{a}$ and $5 \mathrm{~b}$.

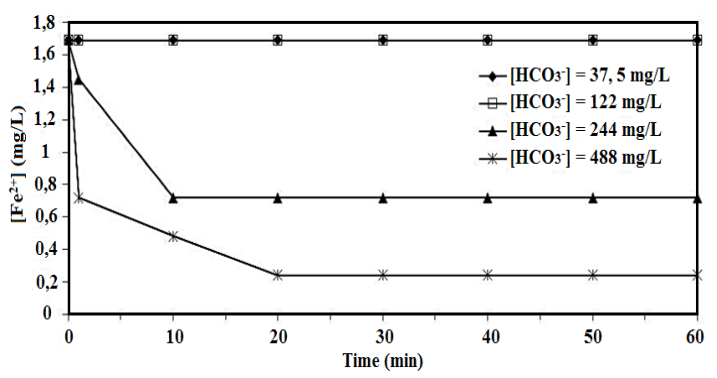

Fig. 5a. Evolution of the dissolved iron content during iron precipitation at differentconcentrations $\left[\mathrm{HCO}_{3}{ }_{3}^{-}\right] ; \mathrm{pHi}=7.35$; $\left[\mathrm{Fe}^{2+}\right]_{0}=1.69 \mathrm{mg}$ at $30^{\circ} \mathrm{C}$



Fig. 5b. pH evolution during iron precipitation at different concentrations $\left[\mathrm{HCO}_{3}^{-}\right] ; \mathrm{pHi}=7.35 ;\left[\mathrm{Fe}^{2+}\right]_{0}=1.69 \mathrm{mg} / \mathrm{L}$ at $30^{\circ} \mathrm{C}$
Figure $5 \mathrm{a}$ shows that the precipitation of $\mathrm{Fe}^{2+}$ iron in the stirred carbonate medium is instantaneous and massive as the concentration of bicarbonate increases. The same results were observed for synthetic solutions. For $\left[\mathrm{HCO}_{3}^{-}\right]=37.5$ $\mathrm{mg} / \mathrm{L}$, precipitation is very low or even non-existent, the iron concentration $\left[\mathrm{Fe}^{2+}\right]_{0}=1.69 \mathrm{mg} / \mathrm{L}$ remains constant throughout the operation. For $\left[\mathrm{HCO}_{3}{ }^{-}\right]=244$ $\mathrm{mg} / \mathrm{L}$, precipitation is instantaneous and after one minute of precipitation, the iron concentration drops to $\left[\mathrm{Fe}^{2+}\right]_{0}=1.45 \mathrm{mg} / \mathrm{L}$. After $10 \mathrm{~min}$ of precipitation, the iron concentration drops to $0.72 \mathrm{mg} / \mathrm{L}$ and remains constant throughout the operation. For $\left[\mathrm{HCO}_{3}{ }^{-}\right]=488$ $\mathrm{mg} / \mathrm{L}$, precipitation is instantaneous and after one minute of precipitation, the iron concentration drops to $\left[\mathrm{Fe}^{2+}\right]=0.72 \mathrm{mg} / \mathrm{L}$ and after $20 \mathrm{~min}$ of precipitation, the iron concentration drops to $0.24 \mathrm{mg} / \mathrm{L}$ or $89.80 \%$ iron removal, and remains constant until the end of the experiment. These results can be explained from the speciation of $\mathrm{Fe}$ (II) in aqueous solution. Indeed, the study of the speciation of $\mathrm{Fe}$ (II) in the bicarbonate medium shows that several $\mathrm{Fe}$ (II) complexes can be formed, namely $\mathrm{FeCO}, \mathrm{Fe}(\mathrm{OH})_{2},\left[\mathrm{Fe}\left(\mathrm{CO}_{3}\right)_{2}\right]^{2-}$, $\mathrm{FeHCO}_{3}, \mathrm{Fe}(\mathrm{OH})^{+}, \mathrm{Fe}\left(\mathrm{CO}_{3}\right) \mathrm{OH}-,\left[\mathrm{Fe}\left(\mathrm{HCO}_{3}\right)^{+20,28,29,30,31}\right.$. Some of these complexes contribute to retaining iron in solution. On the other hand, other complexes contribute to a very high precipitation rate of $\mathrm{Fe}$ (II) at certain concentrations of $\mathrm{NaHCO}^{22}$. Fig. $5 \mathrm{~b}$ confirms the increase in $\mathrm{pH}$ during iron precipitation as in the case of synthetic solutions. These results corroborate many works ${ }^{12,22}$.

\section{CONCLUSION}

From the present results, we can conclude as follows:

1. Precipitation method and deferrization unit are appropriate for the deferrization for synthetic solutions and Dan Daji Illela iron poisoning field waters.

2. There is no important precipitation with free bicarbonate deionized water.

3. The precipitation method shows higher iron precipitation capacity for deferrization for synthetic water in high bicarbonate concentration and high initial $\mathrm{pH}$.

4. The precipitation method shows equal iron precipitation capacity for deferrization for Dan Daji Illela iron poisoning field waters as compared to deferrization unit. 
5. The iron removal capacity of precipitation method decreases with a raise in iron (II) concentration contrary to the initial $\mathrm{pH}$ increases for synthetic solution.

\section{ACKNOWLEGMENT}

The authors thank especially to the
Laboratoire de Valorisation des Matériaux utiles, Centre National de Recherche en Sciences des Matériaux, Technopole de Borj Cedria, Tunisie for recording $\mathrm{DRX}$.

\section{Conflicts of interests}

The authors declare that they have no conflict of interest.

\section{REFERENCES}

1. Michael, C. K. Liver Cancer., 2014, 3(1), 31- 40.

2. Amadou, H. ; Mahaman, S. L. ; Manzola, A. S. J. App. Bio., 2014, 80, 7161-7172.

3. Boubakar, H. A. Doctoral thesis U.A.M., 2010, 249-260.

4. Dehou, S. C. Doctoral thesis Univ. Lille.m, 2011, 103-143.

5. Ruiti, M.; Bechir, B. T. In. J. of Innov. App. Stu., 2015, 10, 694-700.

6. Donald, E. I. M. Sc., 1998, 220-229.

7. OMS. Guidelines for drink water quality., 2011, $4^{\text {th }}$ edi., 541-545.

8. OMS. Guidelines for drink water quality., 2017, $4^{\text {th }}$ edi., 564-569.

9. Christelle, N. M. Sc. 2006., 151-159.

10. Anne-Sophie, S. Doctoral thesis Univ. Lorraine., 2012, 255-261.

11. Vong, L. Doctoral thesis Univ. Aix-Marseille., 2008, 171-188.

12. Wided, M. Doctoral thesis Univ. Cathage., 2017, 60-77.

13. Millero, F.J.; Sotolongo, S.; Izaguirre, M. Geochim. Cosmochim. Acta., 1987, 51, 793-801.

14. Chwertmann, U.; Cambier, P.; Murad, E. Clays Clay Miner., 1985, 33, 369-378.

15. Misawa, T.; Hashimoto, K.; Shimodaira, S. Corr. Sci., 1974, 14, 131-149.

16. Schwertmann, U.; Fechter, H. Clay Miner. 1994, 29, 87-92. 17. Gu, X. Y.; Hsu, P. H. Soil Sci. Soc. Am. J., 1987, 51, 469-474.

18. Michaël, D.; Catherine, B.; Florence, M.;
Sébastien, S.; Joachim, S.; Pierpaolo, Z. Bull. Soc. géol., 2002, 173(3), 265-270.

19. Legrand, L.; Savoye, S.; Chausse, A.; Messina, R. Elec. Acta., 2000, 46, 111-117.

20. Magdalena, S. J.; Melchor G. L. V.; Frank, J. M. M. Chem., 2004, 85, 27-40.

21. Schwertmann, U.; Thalmann, H. Clay min., 1976, 11, 189-198.

22. Wang, Z.; Xu C.; Cao, X.; Xu, B. J. Chem. Eng., 2007, 15(3), 433-438.

23. Svetozar, M.; Israel, N. R.; Zvonko, O.; Stanko, P. Croat. Chem. Acta., 2004, 77(1-2), 141-151.

24. Singer, Ph. C.; Stumm, H. Am. Wat. Wor. Ass., 1970, 62(3), 198-202.

25. Mameri, Y. M. Sc., 2010, 163-174.

26. Lee, S.; OH, J.; Shin B. Shigen-to-Sozai., 1999, 115, 815-819.

27. WANG, Z.; Chunchun, X.; CAO, X.; Ben, X. Chin. J. Chem. Eng., 2007, 15(3), 433-438.

28. Music, S.; Dragcevic, D.; Czakonagy, L.; Popovic, S. Croat. Chem. acta., 1997, 70(2), 689-702.

29. Legrand, L.; Abdelmoula, M.; Géhin, A.; Chausse, A; Genin, J. M. R. Electrochim. Acta., 2001, 46(12), 1815-1822.

30. Jagannath, B.; Kyounglim, K.; Walter, D.C. S.; Susan, C. B.; Stephan, M. K.; Janet, G. H.; Stephan, J. H. Swiss Geo. Sci. Meeting., 2016, 14, 133-140.

31. Michaël, D.; Catherine, B.; Florence, M. G.; Sébastien, S; Joachim, S.; Pierpaolo, Z., Bull. Soc. géol. France., 2000, 3, 265-270. 